\author{
Д.С. Дегтярев
}

Раннеиндустриальный этап

в развитии пространства

российского города

(на материалах Томской губернии)

DOI: $10.31518 / 2618-9100-2018-2-7$

УДК 711.1

Выходные данные для цитирования:

Дегтярев Д.С. Раннеиндустриальный этап в развитии пространства российского города (на материалах Томской губернии) // Исторический курьер. 2018. № 2. Статья 7. URL:

http://istkurier.ru/data/2018/ISTKURIER-2018-2-07.pdf
Danil Degtyarev *

\section{The Early Industrial Stage \\ of the Russian Urban Space Development (on the Materials of Tomsk Province)}

DOI: $10.31518 / 2618-9100-2018-2-7$

How to cite:

Degtyarev Danil S. The early industrial stage of the Russian urban space development (on the materials of Tomsk region // Historical courier, 2018, \# 2. Article 7. [Available online:] http://istkurier.ru/data/2018/ISTKURIER-2018-2-07.pdf

Исследование выполнено при финансовой поддержке РФФИ в рамках научного проекта № 18-09-00439 "Алтайский историко-географический комплекс в XVIII - начале XX веках (междисииплинарные исследования и разработка информационной web-nлатформы)».

The present study was funded by RFBR according to the research project № 18-09-00439

Abstract: The author propounds a theoretical framework for the Russian urban space development throughout Russia's entire history. While cities were turning from fortified places into centers of high-tech industry and trade, the structure of urban space also changed. The author formulates his own definition of urban space and proposes four stages of its evolution: traditional, regular, early industrial and industrial. Each stage corresponds to a certain leading function that determines how objects are located over the urban territory. The military function is characteristic of the traditional cities, the administrative function - of the regular stage, functions of trade and transport are typical of the early industrial stage while the industrial stage is characterized by the manufacturing function.

The author pays special attention to the early industrial stage; defines eight indicators of this stage of urban space development. These include reduction of regulating role of general planning; growing number of artificial toponyms; emergence of "large economic territories" at the center, separation of trade and administrative centers, dormitory suburbs and industrial suburbs, increasing role of the suburbs.

The hypothesis is verified by evidence from the Wes-Siberian cities of Tomsk, Barnaul, Biysk and Novonikolaevsk. These were the most developed cities in this region representing different patterns of the Russian provincial cities' evolution in the second half of the 19th - beginning of the 20th century. Nearly all features of the early industrial stage of urban space development can be found in each of the four cities. It would therefore be desirable to apply the hypothesis of the early industrial stage of urban space development to other cities of the late imperial Russia.

Keywords: historical urban studies; city area, suburb; toponym; economic function of city, Russian city; Siberian city.

The article has been received by the editor on 12.09.2018.

Full text of the article in Russian and references in English are available below.

\footnotetext{
* Дегтярев Данил Сергеевич, канд. ист. наук, старший преподаватель кафедры отечественной истории Алтайского государственного университета (г. Барнаул, Россия), e-mail: danildegtyarev@yandex.ru

Degtyarev Danil Sergeyevich, PhD in History, senior lecturer at the department of Russian history of the Altai State University (Barnaul, Russia), e-mail: danildegtyarev@yandex.ru
} 
Аннотация: Предложена теоретическая схема развития пространства русских городов на всём протяжении их истории. По мере того, как русский город превращался из укреплённого места в центр высокотехнологичной промышленности и торговли, менялась и структура городского пространства. Автор предлагает собственное определение городского пространства и выделяет четыре этапа его эволюции: традиционный, регулярный, раннеиндустриальный и промышленный. Каждому из этапов соответствует одна ведущая функция, выполнение которой во многом и определяет, как расположены объекты на городской территории. Для традиционного города это военная функция, для регулярного административная, для раннеиндустриального - торговая и транспортная, для промышленного - индустриальная.

Особое внимание автор обращает на раннеидустриальную стадию и выделяет восемь признаков, доказывающих, что город находится на этой стадии развития городского пространства. Среди них: снижение регулирующей роли генеральных планов, увеличение числа искусственных топонимов, формирование «большой экономической зоны» в центре, дифференциация пространства на торгово-административный центр, жилые окраины и промышленный пригород, резкое возрастание роли пригородной зоны в жизни города.

Для проверки жизнеспособности схемы она сопоставляется с данными о развитии городского пространства в западносибирских городах Томске, Барнауле, Бийске и Новониколаевске - наиболее развитых центрах своего региона, воплощающих разные модели развития городов российской провинции во второй половине XIX - начале XX века. В каждом их этих городов обнаруживается наличие всех или почти всех квалифицирующих признаков. Это позволяет считать желательным приложение гипотезы о наличии особой раннеиндустриальной стадии развития городского пространства и к другим российским городам пореформенной России.

Ключевые слова: историческая урбанистика; городское пространство; селитебная площадь; пригород; топоним; русский город; сибирский город; экономическая функция города.

Российский город был, есть и останется предметом пристального внимания специалистов многих областей, в том числе специалистов по истории ${ }^{1}$, исторической географии ${ }^{2}$ и истории градостроительства ${ }^{3}$. Это касается и диалектики так называемого городского пространства ${ }^{4}$. До сих пор нет общепринятой трактовки этого термина, поэтому отсутствует и общепринятая схема развития этого явления ${ }^{5}$. Существует широкое поле для теоретических построений. Своей целью я вижу выдвижение еще одного подхода к проблеме периодизации развития пространства российских городов. При его создании учитывались исторические и историко-географические факторы, влиявшие на жизнь российского города. Эмпирической базой стали данные о пространственном развитии четырех крупнейших городов Томской губернии (Томск, Барнаул, Бийск и Новониколаевск). С одной стороны, это довольно специфический регион - Сибирь. С другой - именно в Томской губернии ярче, чем в соседних территориях, проявились общероссийские тенденции ${ }^{6}$. Поэтому я полагаю

\footnotetext{
${ }^{1}$ Скубневский В.А.. Гончаров Ю.М. Города Западной Сибири во 2-й половине XIX - начале XX веков: Население. Экономика. Застройка и благоустройство - Барнаул: «Аз Бука», 2007. - 292 с.

${ }^{2}$ Ивонин А.P. Города Западной Сибири в последней четверти XVIII - начале 60-х гг. XIX вв. (динамика городского пространства). Барнаул: Изд-во АлтГАКИ, 2009. - 151 с.

${ }^{3}$ Градостроительство России середины ХІХ - начала ХХ вв. Кн 1-3. - М.: «Прогресс-Традиция», $2001-2010$. Кн. 1. Общая характеристика и теоретические проблемы. М., 2001. - 340 с.; Кн. 3. - М., 2010. Кн. 3. Столицы и провинция. $-616 \mathrm{c.}$

4 Алисов Д.А. Административные центры Западной Сибири: городская среда и социально-культурное развитие (1870-1914). Монография. - Омск: Изд-во ОмГУ, 2006. - 337 с.

${ }^{5}$ Глазычев В.Л. Социально-экономическая интерпретация городской среды. - М.: «Наука», 1984. С. 5-6.

${ }^{6}$ Скубневский В.А.. Гончаров Ю.М. Города Западной Сибири во 2-й половине XIX - начале XX веков: Население. Экономика. Застройка и благоустройство - Барнаул: «Аз Бука», 2007. С. 205.
} 
правомерным обсуждать полученные выводы и применительно к другим частям России, к стране в целом.

Для начала следует определиться с предметом изучения. Им, как было сказано выше, является «городское пространство». Здесь уже долгое время сосуществуют два подхода: географический и социокультурный ${ }^{1}$. В первом случае под пространством понимается некая территория, часть физического мира, занятая городом. Во втором случае речь идет о некоем нематериальном объекте, созданном городским социумом. Попытавшись объединить эти два подхода, я сформулировал свое определение

Городское пространство - это часть географического пространства, преобразованная городским социумом для выполнения возложенных на него функций. Это определение учитывает и географическую, и социально-экономическую и даже духовную составляющую.

Итак, мы имеем дело с очень сложным объектом, лучше сказать - с многоэлементной системой. Изучить все ее стороны оказывается почти невозможно, поэтому неизбежно приходится прибегнуть к редукции. Главным фактором, влияющим на формирование пространства города, я посчитал функции, возложенные обществом на ту его часть, которая живет в данном месте. Функциональный подход позволит временно отстраниться от изучения других факторов. В результате должна получиться некоторая схема, объясняющая логику развития пространства российского города. Естественно, что историческая реальность будет соответствовать ей лишь отчасти.

\section{1. Логическая схема развития пространства российских городов.}

Само слово «город» в русском языке происходит от слова «городить». То есть город изначально - это укрепленное, защищенное, «огороженное» место. Таким образом, начиная с VIII века, когда возникли первые восточнославянские города, основной функцией этих населенных пунктов была военно-оборонительная. Средневековая Русь почти не знала каменных замков феодалов, поэтому спастись от военной угрозы наши предки могли только в городах. Кроме того, древнерусские города выполняли политические, экономические (центр ремесла и торговли) и культурные (религиозный центр) функции. Но преобладающей все же была функция военная. Этим и обусловлена пространственная структура древнерусских городов. Организация пространства всецело зависела от местных природногеографических условий. В центре поселения находилось укрепление - крепость, далее посад (часто неукрепленный), еще далее - пояс слобод (часто это отдаленные части города, отделяемые реками или оврагами). Важные для общества военно-оборонительная, а также политическая и религиозная функции выполнялись крепостью, на посад и слободы возлагались экономические функции ${ }^{2}$. Выполнением их в случае военной опасности можно было и пожертвовать.

Таким образом, тип пространственной организации городов, когда они выполняли в основном военную функцию, я условно обозначаю как «русский классический город» или «русский традиционный город». Основные признаки: полная зависимость планировки от природных условий местности, четкое разделение на укрепленную и неукрепленную части, отсутствие четкого и однозначного плана пространственного развития, что делало пространство города «эластичным». Именно этим объясняется то, что древнерусские города неоднократно переносились с места на место: на новом месте возникала новая пространственная структура, но с тем же названием и с теми же принципами организации.

Создание в XVI веке мощного централизованного государства резко снизило уровень военной угрозы в его центральной части. Последний раз серьезная опасность угрожала

\footnotetext{
${ }^{1}$ Алисов Д.А. Культура городов Западной Сибири. Вторая половина ХIX - начало XX века: учеб. Пособие / Д.А. Алисов. - Омск: «Полиграфист», 2002. С. 6-7.

2 Бунин А.В., Саваренская Т.Ф. История градостроительного искусства. Градостроительство рабовладельческого строя и феодализма. Том первый. - М.: Стройиздат, 1979. С. 288; Шахеров В.П. Города Сибири в дореформенный период: учебное пособие. - Иркутск: Изд-во ИГУ, 2013. С. 83.
} 
городам Центра России в начале XVII века (Смутное время). В течение следующего столетия военная функция многих городов стала угасать. Это, однако, не относится к городам на окраинах государства (например, в Сибири, на Украине и т.п.). Постепенно главной функцией многих городов стала административная: города превратились в центры управления, в том числе управления экономикой и культурой.

Утверждение русского города в качестве, прежде всего, административного центра произошло в XVIII веке. Именно в это время в пространстве городов происходят коренные изменения. Петр I заложил, а Екатерина II укрепила традицию создания регулярных городов, развитие которых происходит не стихийно, а в соответствии с планом. Это объяснимо: если город - важнейшее звено в системе управления обществом, то государство регулирует его жизнь ${ }^{1}$. Так вместо «русского традиционного города» возник «русский регулярный город». Основные признаки городов этого типа: наличие генерального плана развития, преобладание геометрически правильных форм при делении на сегменты, игнорирование природных особенностей, неэластичность всей пространственной организации, трансформация укрепленной части в центр с открытыми границами. Таким образом, пространственная организация русских городов стала менее гибкой, хотя внутри города исчезла видимая граница между его частями. Возросла связность пространства в рамках всего поселения. Если раньше «неэластичным» элементов с городе была крепостная стена, то теперь неэластичной стала вся структура поселения.

Наступление эпохи индустриализма в XIX веке выдвинуло на первый план экономические функции городов. Теперь уже город мыслился, прежде всего, как центр промышленности, торговли и транспортный узел. Остальные функции (административная, культурная, военная) сохранялись, но отходили на второй план. Меняется и пространственная организация. Выполнение городами экономических функций было территориально разнесено: торговля осуществлялась в основном в центре, а промышленное производство и транспортная функция - на окраинах и в пригороде. Возникновение пригорода как важнейшей неотъемлемой части городского пространства - вот то, что отделило города нового типа от старых регулярных поселений. Если раньше выгон использовался лишь для аграрных занятий горожан, то теперь там расположились заводы, фабрики и станции с пристанями. Однако и аграрная функция за городами также сохранялась. Города России перешли на новую стадию, которую я назвал «русский раннеиндустриальный город». Признаки такого города: преобладание экономических функций над всеми остальными (при этом в комплексе экономических функций главенствует еще не промышленная, а торговая и транспортная); возникновение трехчастной структуры пространства «центр - окраины пригород» при равнозначности для города всех трех частей; разрушение жесткой заранее заданной схемы развития пространства и возвращение к принципу соответствия городских функций и местных географических условий. Последнее привело к тому, что старые генеральные планы стали тормозом на пути развития городов, их повсеместно нарушали и создавали новые - на других принципах. При этом регулярный характер застройки в целом сохранялся - изменилась лишь степень жесткости этой структуры.

Во второй четверти XX века совершился последний до сих пор переход к новому типу городов. Индустриализация страны сделала промышленность главной отраслью нашей экономики, а промышленную функцию - главной функцией ее городов. На место раннеиндустриального города пришел «советский индустриальный город». Городская черта расширилась, и промышленность оказалась уже не в пригороде, а внутри селитебной зоны. Это резко снизило роль пригорода, сведя ее к месту отдыха и реализации все еще сохраняющейся аграрной функции. Новый город приобрел следующую структуру: административно-культурный центр - промышленно-селитебная периферия - аграрнорекреационный пригород. Вновь, как и в XVIII веке, город теперь мыслился в полном отрыве от места, на котором он стоит. Отсюда абстрактные модели «социалистических городов»,

\footnotetext{
${ }^{1}$ Бунин А.В., Саваренская Т.Ф. Указ. соч. С. 451.
} 
«городов-садов» и т.п. Вновь возросла роль генерального плана и выросла степень жесткости пространственной структуры.

Таким образом, на протяжении всей истории русского градостроительства можно выделить четыре типа городов с различной пространственной структурой (см. таблицу).

Таблища.

\section{Этапы пространственной эволюции русских городов}

\begin{tabular}{|l|l|l|l|}
\hline \multicolumn{1}{|c|}{ Тип города } & Основная функция & \multicolumn{1}{|c|}{$\begin{array}{c}\text { Степень жесткости } \\
\text { структуры }\end{array}$} & $\begin{array}{l}\text { Соответствие локальным } \\
\text { географическим условиям }\end{array}$ \\
\hline $\begin{array}{l}\text { Русский } \\
\text { традиционный }\end{array}$ & Военная & $\begin{array}{l}\text { Свободная, но с } \\
\text { наличием жесткой } \\
\text { границы между центром } \\
\text { (крепостью) и } \\
\text { окраинами (посадом) }\end{array}$ & $\begin{array}{l}\text { Зависимость от природных } \\
\text { условий, четкое следование } \\
\text { условиям местности. }\end{array}$ \\
\hline $\begin{array}{l}\text { Русский } \\
\text { регулярный }\end{array}$ & Административная & $\begin{array}{l}\text { Отсутствие жестких } \\
\text { внутренних границ в } \\
\text { городе при возрастании } \\
\text { неэластичности всей } \\
\text { системы. }\end{array}$ & $\begin{array}{l}\text { Постоянное игнорирование } \\
\text { местных условий. }\end{array}$ \\
\hline $\begin{array}{l}\text { Русский ранне- } \\
\text { индустриальный }\end{array}$ & $\begin{array}{l}\text { Экономические } \\
\text { (торговая, } \\
\text { транспортная, } \\
\text { промышленная) }\end{array}$ & $\begin{array}{l}\text { Рост эластичности } \\
\text { системы, разрушение } \\
\text { «плановых» рамок }\end{array}$ & $\begin{array}{l}\text { Учет местных условий, } \\
\text { однако не полная } \\
\text { зависимость от них. }\end{array}$ \\
\hline $\begin{array}{l}\text { Советский } \\
\text { индустриальный }\end{array}$ & Промышленная & $\begin{array}{l}\text { Рост жесткости } \\
\text { системы, возвращение к } \\
\text { традициям генеральных } \\
\text { планов }\end{array}$ & $\begin{array}{l}\text { Игнорирование местных } \\
\text { условий, город как } \\
\text { прирактая модель без ее } \\
\text { месту. }\end{array}$ \\
\hline
\end{tabular}

С учётом предложенной периодизации можно выделить некоторые закономерности в эволюции русского градостроительства. Во-первых, города в целом эволюционировали из военно-политических в экономические центры. Во-вторых, периоды, когда пространство города коррелировало с местными природными условиями, чередовались с этапами, когда этими условиями пренебрегали. В-третьих, этапы, когда природными условиями пренебрегали, совпадают с периодами, когда возрастала жесткость всей системы городского пространства. Можно предположить, что на этапах русского регулярного и советского индустриального города сам город мыслился как абстрактная пространственная модель, которую потом прикладывали к конкретному месту на карте. В то же время русский традиционный и русский ранеиндустриальный город - это результат градостроительства, опирающегося на уже данные условия. Именно поэтому в советской литературе по архитектуре и градостроительству содержится положительная оценка эпохи классицизма (стадия «регулярного города») и негативная оценка городов эпохи капитализма («раннеиндустриальный город»).

\section{2. Пространство раннеиндустриального города.}

Как уже сказано, модернизация российского общества в XIX веке привела и к изменению способа организации городских пространств. Промышленность дореформенной, да и пореформенной России еще была слабой, а на периферии государства почти отсутствовала. Однако появление промышленных предприятий поставило перед градостроителями задачу определить их место в структуре поселения. В эпоху «регулярных» городов предприятия было принято выносить за городскую черту - по соображениям пожарной безопасности и по 
санитарным нормам ${ }^{1}$. Именно поэтому промышленность раннеиндустриального города тоже в основном оказалась за пределами селитьбы. Но если мелкие кустарные предприятия дореформенной эпохи не играли заметной роли в жизни большинства городов, то новые производства зачастую уже фабричного типа стали значимым фактором городской жизни. Постепенно количество предприятий возросло настолько, что они стали определять вектор развития населенного пункта. При этом сами предприятия располагались за его чертой. Так возник индустриальный пригород. Вокруг производств выросли рабочие поселки, в которых проживали сотни и даже тысячи человек, формально причисленных в городским жителям. В этих поселках были построены школы, церкви и даже электротеатры. В итоге пригород стал не просто значимой, а жизненно необходимой частью города.

Развитию промышленности сопутствовало еще более бурное развитие транспорта вначале речного, а затем железнодорожного. И если пристань часто находилась недалеко от старого городского центра, то железнодорожная станция в большинстве случаев выносилась либо на окраину, либо все в тот же пригород. При ней также возникал свой поселок. Если в районе города железная дорога пересекала реку, то пристань для перевалки грузов чаще тоже строилась за городской чертой. Таким образом, в пригороде оказались и индустрия и транспорт. Они, в свою очередь, как магнит притягивали к себе застройку собственно города. В итоге стали быстро расти окраины. Также на периферии городской территории охотнее селились вчерашние крестьяне, что тоже стимулировало рост окраин. Так в городе сформировалась трехчастная система: старый центр - новые окраины - новый пригород.

Центр в это время также трансформировался. Все большее значение в жизни городов играла торговля, которая с предыдущих времен была сконцентрирована вокруг главной базарной площади. Теперь же в крупных центрах стали складываться целые торговые улицы и торговые кварталы. Рост товарооборота сделал необходимым строительство многочисленных складов, в результате чего торговая зона превратилась в торговоскладскую. Склады также строились рядом с транспортными объектами (пристани, станции, транзитные тракты). В тех случаях, когда главная базарная площадь, торговые кварталы и пристань оказывались сравнительно недалеко друг от друга, происходило их территориальное сращивание в единую функциональную зону, которую я условно назвал «экономической». Она, таким образом, занимала почти весь старый центр. Неподалеку располагались также основные административные здания и учреждения культуры, в том числе соборные храмы.

Дифференциация пространства происходила и на окраинах, где также выделялись свои локальные центры общественной жизни. Прежде всего это - торговые площадки, реже храмы или училища. Но основной функцией периферии была вся-таки селитебная (жилая), так как проживание в центре для основной массы горожан было не по карману.

Таким образом, в полностью сформированной системе городского пространства на раннеиндустриальном этапе наблюдалось следующее разделение функций: в центре торговая, отчасти транспортная, а также административная и культурная; на периферии селитебная, отчасти - промышленная и культурная; в пригороде - промышленная и транспортная, а также аграрная и рекреационная (но эти функции были второстепенными для города в целом).

В этой ситуации значение старых генеральных планов развития неуклонно снижалось. Экономический интерес диктовал прагматический подход к городскому пространству, а реализация абстрактных моделей (пусть и эстетически привлекательных) сильно этому мешала. Поэтому повсеместно либо принимались новые планы, либо систематически нарушались существующие. Процесс принятия новых генеральной планов усложнялся участием в их обсуждении выборного городского самоуправления. В результате на принятие нового плана уходили десятилетия, что приводило к устареванию проекта чуть ли не в

\footnotetext{
${ }^{1}$ Ивонин А.P. Города Западной Сибири в последней четверти XVIII - начале 60-х гг. XIX вв. (динамика городского пространства). Барнаул: Изд-во АлтГАКИ, 2009. С. 93.
} 
момент его утверждения. Элемент стихийности в развитии городов нарастал. При этом нужно понимать, что стихийность была продиктована не стремлением разрушить прежнюю пространственную структуру, а практическим интересом как всего городского сообщества, так и отдельных частных лиц (например, купцов и промышленников). Города росли вне планов, но это не сдерживало их развитие, а чаще даже подстегивало его.

Система деления городской территории тоже менялась. Привычное для регулярного города членение на полицейские части сохранялось, но все чаще использовалась и неофициальная система районирования. Постепенно народные названия территорий становились официальными наименованиями административных частей города.

Даже системы ориентации в городском пространстве претерпевали в это время серьезные изменения. Речь идет об адресах и топонимии. Если раньше в составе адреса обязательно фигурировала фамилия собственника, то теперь он стал принимать привычную для нас форму «район - улица - номер дома - номер квартиры». А среди названий городских объектов стало возникать все больше искусственных конструкций (например, улицы в честь выдающихся личностей).

Таким образом, пространство раннеиндустраильного города уже сильно отличалось от пространства города регулярного. Можно выделить несколько определяющих признаков, по которым можно идентифицировать именно раннеиндустриальный город.

1. Преобладание экономических функций надо всеми остальными.

2. Систематическое нарушение генеральных планов или их отсутствие.

3. Смешение официального и неофициального районирования.

4. Обезличивание адресов.

5. Увеличение числа искусственно созданных внутригородских топонимов.

6. Формирование экономической функциональной зоны в центре города.

7. Четкое деление города на три части: торгово-административный центр - жилые окраины - промышленный пригород.

8. Возрастание роли пригорода в жизни города, перенос туда ряда важных функций.

Наличие всех или большинства этих признаков в том или ином городе позволяет нам говорить о том, что его пространство находится на раннеиндустриальном этапе развития. Теперь предстоит проверить - отвечают ли этим признакам города Томской губернии во второй половине XIX - начале XX вв.

\section{3. Пространство крупных городов Томской губернии во второй половине XIX - начале XX вв.}

Очевидно, что трансформация пространственной структуры быстрее происходила в крупных городах с наибольшей численностью населения. Именно поэтому я в первую очередь рассматриваю ситуацию в Томске, Барнауле, Бийске и Новониколаевске. Историческая судьба этих населенных пунктов складывалась по-разному, что накладывало определенный отпечаток и на их пространственное развитие.

Губернский город Томск во второй половине XIX в. из преимущественно административного центра превращался в важный торгово-транспортный узел. Томское купечество наряду с тобольским, тюменским и барнаульским становится самым влиятельным в Западной Сибири. Дополнительный толчок развитию Томска дало железнодорожное строительство, что стимулировало рост промышленного производства. В результате город к началу XX столетия мог считаться не только торговой «столицей» всего края, но и крупнейшим индустриальным центром губернии ${ }^{2}$. Налицо преобладание экономических функций над остальными.

Под влиянием означенных перемен быстро трансформировалось городское пространство. Генеральный план 1830 г. безнадежно устарел уже к 60-м гг. XIX в. После этого в течение

2 Дмитриенко Н.М. Сибирский город Томск в XIX - первой трети XX века: управление, экономика, население. - Томск: Изд-во ТГУ, 2000. С. 18. 
20 лет власти пытались создать и утвердить новый генеральный план. Процесс завершился только в 1883 г., но к тому времени и новый план перестал соответствовать потребностям быстро растущего города ${ }^{3}$. Попытки принять очередной план в начале XX в. провалились.

Для Томска всегда было характерно смешение деления официального (на полицейские части или районы) и неофициального (на части города). Причем именно неофициальное деление все больше определяло и административные границы, и вообще всю систему ориентиров в городском пространстве. Процессы модернизации, впрочем, затронули и другие системы ориентации - адреса и топонимию. Адрес томича более ста лет назад уже был похож на современный ${ }^{4}$. А вот топонимы еще долгое время сохраняли традиционный характер. В городе было мало улиц с порядковыми номерами или названных в честь выдающихся людей (исключение составляют лишь «монархические» годонимы).

Функциональное зонирование Томска претерпело сильные изменения. В центре города на Уржатке, в районе Базарной площади и пристаней - сформировалась «экономическая зона», объединявшая торговые и складские помещения и транспортный узел. Население постепенно перемещалось из центра на окраины, где росла этажность домов. Внутри самих окраин также происходила кристаллизация местных центров ${ }^{5}$.

Значительно расширился и томский пригород. На пригородную зону Томска были возложены частично или почти полностью многие городские функции. Во-первых, это функции экономического характера - промышленная, аграрная, и частично торговая и транспортная. Во-вторых, селитебная функция. В-третьих, функции культурная и религиозная. И, наконец, именно пригород был основной рекреационной зоной Томска. Частично пригород выполнял и административную функцию (прежде всего, там находились объекты пенитенциарной системы $)^{6}$. Все это обусловливало рост населения пригорода, которое непосредственно обеспечивало выполнение всех этих функциональных задач. Точных данных о числе жителей пригорода на разных этапах его существования пока нет, но по косвенным сведениям можно предположить, что оно составляло от 2-3 тыс. чел. (конец XIX века) $)^{7}$ до 10 тыс. чел. к 1917 году, то есть до $10 \%$ всех жителей Томска. Разнообразие выполняемых пригородом Томска функций привело к разнообразию расположенных там объектов. В районе Томска в начале XX века наблюдался процесс превращения старожильческих деревень, население которых ранее занималось лишь сельским хозяйством, в пригородные поселения, ориентированные на товарное производство для нужд города. В результате сложились предпосылки для возникновения Томской агломерации - сложного пространственного образования, включающего не только сам город, но и многочисленные окрестные деревни.

Итак, из восьми признаков раннеиндустриального города в Томске налицо семь; ясно, что в начале XX в. этот город действительно находился на раннеиндустриальной стадии пространственного развития.

Второй по величине и значимости город Томской губернии - Барнаул. Его особенность заключалась в том, что для Барнаула экономическая функция с самого начала была основной, так как это был всероссийский центр производства серебра. Закрытие сереброплавильного завода в 1893 г., впрочем, не изменило ситуации: город превратился в центр торговли и обрабатывающей промышленности. С появлением Алтайской железной дороги Барнаул стал еще и важным транспортным узлом. Таким образом, экономические функции оставались главными для Барнаула.

\footnotetext{
${ }^{3}$ Государственный архив Томской области (ГАТО). Ф. 6. Оп. 1. Д. 1591. Л. 60.

${ }^{4}$ ГАТО Ф. 199. Оп. 1. Д. 29. Л. 2.

5 Алисов Д.А. Административные центры Западной Сибири: городская среда и социально-культурное развитие (1870-1914). Монография. - Омск: Изд-во ОмГУ, 2006. С. 115.

${ }^{6}$ Дегтярев Д.С. Пригородные зоны городов Томской губернии во второй половине ХІХ - начале XX вв. Барнаул: Азбука, 2012 С. 38-40.

${ }^{7}$ Скубневский В.А.. Гончаров Ю.М. Города Западной Сибири во второй половине ХІХ - начале XX века. Экономика. Население. Застройка и благоустройство. Барнаул: «Азбука», 2007. С. 188.
} 
Генеральный план Барнаула был принят в 1837 г., но уже во второй половине XIX в. он устарел. Все попытки принять новый план, которые предпринимались в речение почти 50 лет, оказались безуспешными. Фактически в начале XX в. Барнаул жил без всякого плана, развиваясь отчасти на старом заделе, отчасти - согласно практическим соображениям. Даже расширение городской черты в Барнауле было произведено позже. чем в других городах Томской губернии (в Томске, Кузнецке, Каинске и даже Новониколаевске оно состоялось в 1910 г., а в Барнауле - только в 1915 г. $)^{8}$.

Основой районирования Барнаула всегда было официальное деление. Однако к началу $\mathrm{XX}$ в. в официальное делопроизводство проникла «народная» топонимия, а ведомственные участки стали соотноситься с неофициальными районами (например, выделялись Нагорная и Зайчанская части). Впрочем, в Барнауле этот процесс не был таким явным, как в Томске.

Что касается развития систем ориентации в городском пространстве, то в Барнауле происходили те же процессы, что и в Томске. Адрес становился все более похожим на современный; появились даже адреса домовладений с литерами и нумерация квартир внутри одного дома ${ }^{9}$. Количество стандартизированных и мемориальных годонимов также возросло. К 1917 г. в Барнауле насчитывалось 12 Алтайских улиц и не менее 7 Прудских переулков; часть улиц была названа в честь писателей (Пушкина, Гоголя, Льва Толстого), часть - в честь местных администраторов и героев (Болдыревский, Суховский, Добротинский переулки $)^{10}$.

Город отчетливо разделился на торгово-административный центр, густонаселенные окраины и промышленный пригород. В центре, вокруг Базарной площади. вдоль улиц Луговых и Льва Толстого до Оби и пристаней оформилась «экономическая зона», где множество складов соседствовало с крупными торговыми центрами. Основная масса населения Барнаула проживала на периферии: в Нагорной части в то время жил чуть ли не каждый третий барнаулец ${ }^{11}$. Ну, а промышленность почти полностью «переехала» за городскую черту; к 1913 г. более 3/4 предприятий города находилось либо в пригороде, либо на окраине, но близко к границе селитебной зоны ${ }^{12}$.

Барнаульский пригород не был таким развитым, как пригород Томска, но выполнял в основном те же функции. Впрочем, транспортная функция здесь представлена меньше, так как железнодорожная станция буквально в процессе сооружения оказалась в пределах городской черты, а пристани там были давно. Меньшим был и процент «пригородных» жителей. Медленнее шел процесс формирования агломерации, так как перенос промышленности в пригородные села на Алтае только начинался ${ }^{13}$.

Итак, можно видеть, что и Барнаул находился на той же стадии развития, что и Томск, был раннеиндустриальным городом. Здесь обнаруживается проявление всех восьми квалифицирующих признаков.

Третьим по величине и по значению городом в регионе был уездный центр Бийск. В этом городе очень четко проявилась смена ведущих функций: Бийск вначале был пограничной крепостью, затем - административным центром, в том числе центром русской колонизации Горного Алтая. А в конце XIX в. город становится важнейшим торговым узлом; именно здесь происходила перевалка грузов с гужевого транспорта на речной, именно здесь начинался международный торговый путь - Чуйский тракт в Монголию и Китай. К 1917 г. Бийск стал не только «торговой столицей» южной части региона, но и значимым центром

\footnotetext{
${ }^{8}$ Государственный архив Алтайского края (ГААК). Ф. 52. Оп. 1. Д. 35. Л. 53-54.

${ }^{9}$ ГААК Ф. 52. ОП. 1. Д. 70. Л. 99, Д. 72. Л. 92.

${ }^{10}$ ГААК Ф. 52 ОП. 1. Д. $188-191$.

${ }^{11}$ Алтайский сборник Т.2. выпуск 1 и 2. - Барнаул, 1898. С. 31.

12 ГААК. Ф. 52. Оп. 1. Д. 20. Л. 147-150.

13 Дегтярев Д.С. Пригородные зоны городов Томской губернии во второй половине XIX - начале XX вв. Барнаул: Азбука, 2012 С. 38.
} 
промышленного производства; достаточно сказать, что здесь работала крупнейшая частная текстильная фабрика всей Западной Сибири ${ }^{14}$.

Генеральный план города был принят в 1834 г., но через 30 лет оказался несовременным. Новый план разрабатывали и принимали еще около 20 лет; проект был утвержден только в 1886 г. Однако и он в начале XX века устарел, особенно после присоединения к Бийску Заречного предместья. Возникновение железнодорожной станции в пригороде окончательно разрушило принципы, заложенные в прежних планах.

В Бийске весьма ярко проявилось смешение официального и неофициального деления. Это выразилось в том, что полицейские части точно совпадали в исторически сложившимися городскими районами, получив даже названия из «народной» топонимии. А вот годонимы Бийска оказались менее подвержены модернизации: в городе не было «номерных» названий, а мемориальные возникли весьма поздно (улицы Пушкина, Гоголя, Муромцевский пер.). То же самое можно сказать и об адресной системе - она была еще довольно архаичной ${ }^{15}$.

Складывание трехчастной системы в данном городе происходило весьма медленно. В центре так и не сложилось «экономической зоны», так как торговая площадь и пристани находились далеко друг от друга. Впрочем, основная масса населения Бийска проживала все же на периферии, где также возникали местные центры (например, Ярмарочная площадь в Казанке, храмы в Форштадте и Заречье). В состав бийского пригорода входили пять различных типов поселений, множество отдельных объектов и несколько ярко выраженных функциональных зон. По разнообразию состава объектов пригородной зоны Бийск уступал Томску и Барнаулу. Результатом эволюции пригорода Бийска стало его превращение в крайне важную для функционирования города часть его пространства. Пригород выполнял ряд важных городских функций (промышленная, аграрная, селитебная, транспортная, рекреационная). На долю пригорода приходилось две трети площадей городского пространства, 10 \% жителей города ${ }^{16}$, почти весь промышленный потенциал Бийска и зоны его внешнего транспорта. По уровню развития пригородной зоны Бийск намного опередил малые города региона и почти сравнялся с крупными.

Подводя итог, можно сказать, что и Бийск, несмотря на свои сравнительно небольшие размеры, уже в значительной мере был раннеиндустриальным городом. Из восьми признаков выявлено наличие пяти, то есть более $50 \%$.

Четвертым в ряду рассматриваемых примеров я бы хотел сделать Новониколаевск. По числу жителей, да и по общему уровню развития он к 1917 г. догнал Томск ${ }^{17}$. Главной особенностью Новониколаевска была его молодость: город возник в самом конце XIX в. Поэтому к нему, как мне думается, нельзя применять ту же шкалу признаков, что и к старым городам. Едва ли имеет смысл говорить об устаревании генерального плана, правильнее говорить о его позднем (или раннем) принятии. Кроме того, я бы исключил из перечня признаков формирование «экономической зоны» в центре города, так как этот процесс связан с трансформацией уже имеющейся структуры. В остальном в Новониколаевске можно и нужно поискать признаки раннеиндустриального города.

Само появление нового города на Оби было связано с экономическим развитием, а именно - c сооружением Транссибирской железной дороги. Поселок на пересечении магистралью судоходной реки Оби за 10 лет дорос до крупного городского центра, выполнявшего экономические функции. Административный статус у Новониколаевска был наименьшим - безуездный город. Зато он стал важнейшим транспортным узлом, местом перевалки грузов с реки на железную дорогу, центром местной торговли и местом

\footnotetext{
${ }^{14}$ Гончаров Ю. М., Литягина А. В. Очерки истории города Бийска (вторая половина ХІХ - начало ХХ века Барнаул: Издательство «Аз Бука», 2009. С. 10-11.

${ }^{15}$ ГААК Ф. 174. ОП. 1. Д. 38. Л. 14об.

16 Скубневский В.А.. Гончаров Ю.М. Города Западной Сибири во второй половине ХІХ - начале ХХ века. Экономика. Население. Застройка и благоустройство. Барнаул: «Азбука», 2007. С. 188.

${ }^{17}$ Горюшкин Л.М., Бочанова Г.А.. Цепляев Л.Н. Новосибирск в историческом прошлом. - Новосибирск: Изд-во «Наука». Сибирское отделение, 1975. С. 286.
} 
сосредоточения крупной обрабатывающей промышленности (например, мукомольной $)^{18}$. Все это стимулировало приток населения, что делало селитебную функцию второй по значению после экономической.

Новониколаевск стал городом в 1903 г., а его первый генеральный план был принят в 1909 г., то есть довольно рано. Нужно учесть еще и то, что новое поселение с самого основания развивалось на регулярной основе. Можно сказать, что даже в разгар «раннеиндустриальной» эпохи здесь искусственно воспроизводился предыдущий этап логической схемы развития пространства. Впрочем, дальше все пошло по известной схеме: принятый план устарел уже на следующий год, когда была расширена городская черта ${ }^{19}$.

Официальное и неофициальное районирование Новониколаевска складывались одновременно. И сразу же они были неразделимы: полицейские части носили «народные» названия, а их границы совпадали с естественным делением города на районы. Еще нагляднее демонстрирует уровень развития системы города положение с адресной и топонимической системой. Адрес жителя Новониколаевска сразу складывался как обезличенный; в документах почти невозможно встретить указание на домовладение без номера по улице или хотя бы без номера квартала ${ }^{20}$. В городе почти не было «номерных» годонимов. зато по числу мемориальных названий улиц Новониколаевск занимал одно из первых мест в губернии. Из 133 улиц, упомянутых в списке за 1925 г., 46 имели мемориальные названия, что составляет около $35 \%$ от общего числа ${ }^{21}$.

Как уже говорилось. «экономическая зона» в центре Новониколаевска не сложилась, зато ее подобие сформировалось между железной дорогой и берегом Оби. Здесь были сконцентрированы крупные промышленные предприятия, склады и перевалочная пристань. В отличие от старых экономических зон в этой почти отсутствовала торговля, которая осуществлялась именно в центральных кварталах, вокруг старой и новой Базарной площадей.

В то же время дифференциация ролевых поясов в Новониколаевске шла полным ходом. Промышленность почти целиком оказалась в пригороде, а основная масса населения - в периферийной Закаменской части и на севере Центральной (тоже фактически окраина). Впрочем, к 1917 г. складывание классической трехчастной схемы здесь было еще далеко от завершения. Оценивая уровень развития пригородной зоны Новониколаевска, можно отметить, что он был невысок. В отличие от собственно города пригород не получил должного развития. Кроме того, его наиболее развитая часть быстро срослась с городом и стала его частью. В то же время пригород имел тенденции к территориальному расширению и к пополнению новыми поселениями за счет включения в его состав окрестных деревень. Численность населения новониколаевского пригорода составляла максимум до 2,5 тыс. чел., что не превышало 8 \% от общего числа городских жителей ${ }^{22}$.

В целом Новониколаевск к 1917 г. также уже находился на раннеиндустриальной стадии развития. Даже если считать не обнаруженными два из вышеназванных признаков (6-й и 8-й), то шесть остальных проявляются в полной мере. Впрочем, нужно понимать, что фантастическая скорость, с которой рос и развивался этот город, накладывала свой отпечаток. Стадии развития его пространства смешивались; здесь в одно и то же время можно было обнаружить и признаки регулярного, и признаки раннеиндустриального города, а вскоре стали проявляться и признаки следующего - «промышленного» этапа.

Я намеренно не останавливаюсь на прочих городах Томской губернии. Все это были не очень крупные поселения, скорость протекания процессов там была ниже. Перечень

\footnotetext{
${ }^{18}$ Горюшкин Л.М., Бочанова Г.А.. Цепляев Л.Н. Новосибирск в историческом прошлом. - Новосибирск: Изд-во «Наука». Сибирское отделение, 1975. С. 249-250.

${ }^{19}$ ГАТО Ф. 196. Оп. 4. Д. 221. Л. 50-53.

${ }^{20}$ ГАТО Ф. 3. Оп. 23. Д. 279. Л. $280 б$.

21 Весь Новониколаевск 1924-1925. Адресно-справочная книга с краткой историей и планом города. Новониколаевск: Новониколаевское сибирское отделение РОСТА, 1925. С. 187-193.

${ }^{22}$ ГАТО Ф. 200. Оп. 1. Д. 11. Л. 110-112.
} 
признаков для них, скорее всего, будет несколько иной. Раннеиндустриальная стадия развития пространства в малых городах требует отдельного исследования. Что же касается четырех крупнейших городов Томской губернии, то в каждом из них мне удалось найти все или почти все признаки данной стадии. Таким образом, эмпирические данные подтверждают и гипотезу о существовании самой этой стадии, и прохождение через эту стадию развития в начале XX в. таких разных городов, как Томск, Барнаул, Бийск и Новониколаевск. Можно предположить, что все города России того времени, достигшие определенного уровня развития, имели сходную пространственную структуру.

\section{Статья поступила в редакцию 12.09.2018 г.}

\section{Лumepamypa}

Алисов Д.А. Административные центры Западной Сибири: городская среда и социальнокультурное развитие (1870-1914). Монография. - Омск: Изд-во ОмГУ, 2006. - 337 с.

Алисов Д.А. Культура городов Западной Сибири. Вторая половина XIX - начало XX века: учеб. Пособие /Д.А. Алисов. - Омск: «Полиграфист», 2002. - 195 с.

Бунин А.В., Саваренская Т.Ф. История градостроительного искусства. Градостроительство рабовладельческого строя и феодализма. Том первый - Москва: Стройиздат, 1979. 496 с.

Весь Новониколаевск 1924-1925. Адресно-справочная книга с краткой историей и планом города. Новониколаевск: Новониколаевское сибирское отделение РОСТА, 1925. 200 с.

Глазычев В.Л. Социально-экономическая интерпретация городской среды. - М.: «Наука», 1984. $-180 \mathrm{c.}$

Гончаров Ю. М., Литягина А. В. Очерки истории города Бийска (вторая половина XIX начало XX века - Барнаул: Издательство «Аз Бука», 2009. - 276 с.

Горюшкин Л.М., Бочанова Г.А.. Цепляев Л.Н. Новосибирск в историческом прошлом. Новосибирск: Изд-во «Наука». Сибирское отделение, 1975. - 296 с.

Градостроительство России середины XIX - начала XX вв. - М.: «Прогресс-Традиция», 2003. Кн. 1. Общая характеристика и теоретические проблемы. -340 с.

Градостроительство России середины XIX - начала XX вв. - М.: «Прогресс-Традиция», 2010. Кн. 3. Столицы и провинция. -616 с.

Дегтярев Д.С. Пригородные зоны городов Томской губернии во второй половине XIX начале XX вв. Монография.- Барнаул: Азбука, 2012. - 176 с.

Дмитриенко Н.М. Сибирский город Томск в XIX - первой трети XX века: управление, экономика, население. - Томск: Изд-во ТГУ, 2000. - 282 с.

Ивонин А.P. Города Западной Сибири в последней четверти XVIII - начале 60-х гг. XIX вв. (динамика городского пространства). Барнаул: Изд-во АлтГАКИ, 2009. - 151 с.

Скубневский В.А.. Гончаров Ю.М. Города Западной Сибири во второй половине XIX начале XX века. Экономика. Население. Застройка и благоустройство. Барнаул: «Азбука», 2007. - 292 c.

Шахеров В.П. Города Сибири в дореформенный период: учебное пособие. - Иркутск: Изд-во ИГУ, 2013. - 185 с.

\section{References}

Alisov D.A. Administrativny`e centry`Zapadnoj Sibiri: gorodskaya sreda i social’no-kul’turnoe razvitie (1870-1914) [Administrative centers of West Siberia: urban environment and social and culutral development. (1870-1914)]. Monograph. - Omsk: Izd-vo OmGU, 2006. - 337 p.

Alisov D.A. Kul tura gorodov Zapadnoy Sibiri. Vtoraya polovina XIX - nachalo XX veka [Culture of cities in West Siberia ( $2^{\text {nd }}$ half of the XIX - beginning of the XX c.)]: ucheb. Posobie / D.A. Alisov. - Omsk: «Poligrafist», 2002. - 195 p. 
Bunin A.V., Savarenskaya T.F. Istoriya gradostroitel'nogo iskusstva. Gradostroitel'stvo rabovladel'cheskogo stroya i feodalizma. [History of City-building Art. Epoch of slavery and feudalism] Tom pervyy -M.: Stroyizdat, 1979. - 496 p.

Glazy`chev V.L. Sotsial'no-e'konomicheskaya interpretatsiya gorodskoy sredy' [Socialeconomic interpretation of urban environment]. - M.: «Nauka», 1984. - 180 p.

Goncharov Yu. M., Lityagina A. V. Ocherki istorii goroda Biyska (vtoraya polovina XIX nachalo XX veka [essyas on the history of Biysk ( $2^{\text {nd }}$ half of the XIX - beginning of the XX c.)]Barnaul: Izdatel`stvo «Az Buka», 2009. - 276 p.

Goryushkin L.M., Bochanova G.A.. Ceplyaev L.N. Novosibirsk v istoricheskom proshlom. [Novosibirsk in the historical past] - Novosibirsk: Nauka. Sibirskoe otdelenie, 1975. - 296 p.

Gradostroitel'stvo Rossii serediny` XIX - nachala XX vv. [Russian city-building at the $2^{\text {nd }}$ half of XIX - beginning of XX] - M.: «Progress-Traditsiya», 2003. Kn. 1. Obshhaya xarakteristika i teoreticheskie problemy`. $-340 \mathrm{p}$.

Gradostroitel'stvo Rossii serediny` XIX - nachala XX vv. [Russian city-building at the $2^{\text {nd }}$ half of XIX - beginning of XX] - M.: «Progress-Traditsiya», 2010. Kn. 3. Stolitsy i provintsiya. - 616 p.

Degtyarev D.S. Prigorodny`e zony` gorodov Tomskoy gubernii vo vtoroy polovine XIX nachale XX vv. [Suburbs of cities of the Tomsk region in the $2^{\text {nd }}$ half of the XIX - beginning of the XX c.] Monografiya.- Barnaul: Azbuka, 2012. - 176 p.

Dmitrienko N.M. Sibirskiy gorod Tomsk v XIX - pervoy treti XX veka: upravlenie, e'konomika, naselenie. [Siberian Tomsk in the XIX $-1^{\text {st }}$ third of the XX c.: power, economy, population]Tomsk: Izd-vo TGU, 2000. - 282 p.

Ivonin A.R. Goroda Zapadnoj Sibiri v posledney chetverti XVIII - nachale 60-x gg. XIX vv. (dinamika gorodskogo prostranstva) [Cities of Western Siberia in the last quarter of the XVIII 1860s: dynamics of the city area]. Barnaul: Izd-vo AltGAKI, 2009. - 151 p.

Skubnevskiy V.A.. Goncharov Yu.M. Goroda Zapadnoy Sibiri vo vtoroy polovine XIX nachale XX veka. Ekonomika. Naselenie. Zastroyka i blagoustroystvo [Cities of West Siberia in the $2^{\text {nd }}$ half of the XIX - the beginning of the XX c. Economy. Population. Buildings and Site improvement]. Barnaul: «Azbuka», 2007. - 292 p.

Shakherov V.P. Goroda Sibiri v doreformennyy period [Siberian cities during the period before the Great Reforms]: uchebnoe posobie. - Irkutsk: Izd-vo IGU, 2013. - 185 p.

Ves` Novonikolaevsk 1924-1925. Adresno-spravochnaya kniga s kratkoy istoriey i planom goroda. [All Novonikolaevsk. Reference book with concise history and the map of the city]Novonikolaevsk: Novonikolaevskoe sibirskoe otdelenie ROSTA, 1925. - 200 p. 